3. Curtis, L. (1996, May 5). A case of identity: rescuing Rebecca Clarke, The Musical Times, pp. 15-21.

4. Curtis, L. (2004). A Rebecca Clarke reader, The Rebecca Clarke Society, Inc., 241 p.

5. Luce, Gregory R. (2015). British viola repertoire of the first half of the twentieth century: dissertation, Faculty of the Graduate School of the University of Maryland, College Park, $29 \mathrm{p}$.

6. Rebecca Clarke. List of works. Available at: https://www.rebeccaclarke.org/worksi/ [Accessed 30.01.2018].

7. Riley Maurice W. (1993). The history of the viola, V. I. Braun-Brymfield, Ann Arbor, Michigan, USA, 396 .

УДК 782.1(4-15):430

ORCID:0000-0002-9586-2580

Юрий Зильберман, кадидат искусствоведения, заслуженный деятель искусств Украины, профессор Киевского института музыки им. Р. М. Глиэра ул. Льва Толстого, 31, Киев, 01032, Украина

Yuri Zilberman, Ph.D. in Arts, Honoured Figure of Arts of Ukraine, professor,

R. Glier Kyiv Institute of music, 31 Lva Tolstogo St., Kyiv 01032, Ukraine

\title{
«УПРАВЛЯЕМАЯ ТОЛПА» В ОПЕРЕ-ОРАТОРИИ КАРЛА ОРФА «DIE ВЕRNAUERIN»
}

В статье рассматривается малоизученная опера-оратория К. Орфа «Бернауерин». Автор стремится виявить причины обращения композитора к средневековой балладе в качестве литературной основы либретто, а также определить значение «управляемой толпы» в выбранном произведении.

Ключевые слова: опера-оратория, «театр Карла Орфа», немецкая музыка.

The «controlled crowd» in the opera-oratorio «Die Bernauerin» by Carl Orff. The article is devoted to little studied K. Orff"s opera-oratorio «Die Bernauerin». The author seeks to identify the reasons for the composer's appeal to a medieval ballad as a literary basis of the libretto and also determine the meaning of the «controlled crowd» in the selected work.

Key words: opera-oratorio, «Carl Orff”s Theater», German music.

«Керований натовп» в опері-ораторії Карла Орфа «Die Bernauerin». У статті розглядається маловивчена опера-ораторія К. Орфа «Бернауерін». Автор прагне виявити причини звернення композитора до середньовічної балади як літературної основи лібрето, а також визначити значення «керованого натовпу» в обраному творі.

Ключові слова: опера-ораторія, «театр Карла Орфа», німецька музика. 
Сегодня творчество южно-германского композитора Карла Орфа привлекает не только своей ритмической остротой и остинатностью, а прежде всего художественным смыслом и общечеловеческим содержанием, которые наполняют произведения композитора. На сегодняшний день наиболее известными его сочинениями остаются кантаты «Кармина Бурана», «Катулли Кармина» и «Триумф Афродиты».

Карла Орфа называют «самым ярким представителем музыкального примитивизма» [2], самым крупным приверженцем музыкального традиционализма, человеком театра. Его упрекают за «разрыв традиций в немецкой музыке (от Р. Вагнера к А. Шенбергу)», за решительное «упрощение» выразительных средств, наконец, за его непоколебимую уверенность в том, что музыкант будущего - это певец, актер, мим, танцор, словом - универсал, каким он предстает в операх «Луна», «Умница», «Антигона», «Бернауерин».

Но главное видится не в том, что К. Орф противопоставляет себя «эстетизму» и сложности музыкального языка художников типа Арнольда Шенберга, Антона Веберна и Альбана Берга, а в том, что композитор задумывается над судьбой искусства ХХ в.

Представляется, что отсюда возникает тяга композитора к «упрощению» музыкального языка, к новым составам, в которых ритмическая группа и сам ритм (вернее, его остинатная надсадность) играют главную роль в создании образа. Так называемый «театр Карла Орфа» - это не противопоставление комического начала «Умнuцьь»», «Хитрецуов», «Луныл» трагедиям «Бернауерин», «Антигона», «Царь Эдип», а попытка осмыслить мир как целостное явление - комического и трагического в жизни человека. Конечно, «баварская штучка» - опера-оратория «Die Bernauerin» - играет определенную (если не главную) роль в этой «шестерке».

Анализ литературы дает представление о почти полном отсутствии серьезных исследований в этом вопросе. Есть только два источника, в которых Карл Орф выступает, как композитор - автор множества кантат, опер, произведений для оркестра, хора, солистов - это труд О. Т. Леонтьевой «Карл Орф», изданный в Москве и книга канадского музыковеда Михаэля Катера «The Twisted Muse: Musicians and Their Music in the Third Reich», изданная в Оксфорде. В этой работе автор, по нашему мнению, безосновательно, на основе документов, слухов и рассказов, не используя сочинения композитора, однозначно причисляет его к нацистам. Конечно, существуют статьи, на которые автор ссылается в тексте, как например, «Столетие Орфа» П. Поспелова и А. Грановской, которые, опираясь на того же М. Катера, пишут о «нацизме» К. Орфа [8], или всевозможные биографические эссе. 
Актуальность статьи видится нам в разрешении вопроса: почему композитор Карл Орф обратился к средневековой балладе об Агнес Бернауер в 1944 г.?

Конечно, есть в этом вопросе и «скандальная» составляющая. Особенно, если учесть блоги известных kalakazo и pschutt, которые обвиняют Орфа в предательстве идеалов и ставят под сомнение его участие в антифашистской организации «Белая роза». Подобный намек слышится и в статье П. Поспелова и А. Грановской «Столетие Карла Орфа», опубликованной газетой «Коммерсант» в 1995 г. (к столетию со дня рождения композитора) [8]. В статье пересказывалось обвинение, выдвинутое канадским музыковедом на симпозиуме, организованном Центром Карла Орфа в Мюнхене в 1994 г.: «Основным обвинителем выступил канадский музыковед Михаэль Катер, который выяснил, что после войны Орф пытался ввести в заблуждение союзников: чтобы получить профессиональные льготы, он выдал себя за тайного члена мюнхенской группы сопротивления „Белая роза”. Известно, правда, что свою оперу „Бернауерин” композитор посвятил памяти друга - профессора музыки Курта Хубера, казненного нацистами в 1943 году. Однако также известно, что Орф не подозревал о политической деятельности Хубера, а посвящение приписал только в 1946 году» [8].

Своей задачей автор видит не «обеление» композитора, а в донесении до читателя вопроса, поставленного Карлом Орфом в опере: что может сделать человек, даже уверенный в невиновности обвиняемого, гонимого, преследуемого толпой другого человека? Уже две тысячи лет звучит в устах толпы жуткое: «Отпустите Варраву». Почему? Видимо, в евангельской толпе был «свой монах» (имеется в виду монах, посланный канцлером герцога Мюнхена убить Бернауерин). В истории немало примеров, когда воинствующая чернь громит по наущению предводителя, сметая со своего пути всё и вся. Примеры? Их множество. В XVI в. «Варфоломеевская ночь», когда было уничтожено от 5 до 30 тысяч людей во Франции. Новгородский погром, учиненный Иваном Грозным, унесший, по мнению историков, от 5 до 25 тысяч. Начавшиеся в 1938 г. и по сей день продолжающиеся еврейские погромы и др. Чтобы не перечислять многочисленные примеры, отсылаем читателя к Интернетресурсу: набрав в поисковой системе «массовые беспорядки», можно увидеть множество страниц описаний (около 68000 результатов). Главное, что хотелось бы отметить - это то, что даже не отличающаяся точностью «Википедия» трактует организацию массовых беспорядков однозначно: «Организация массовых беспорядков - действия, направленные на сбор 
толпь, доставка и распространение в толпе оружия, разжигание в толпе агрессивных настроений, руководство толпой в ходе погромов, поджогов, применения насилия, сопротивления органам власти и управления» [7].

А чем была Великая Октябрьская социалистическая революция, если не «массовым беспорядком», учиненным по «велению большевиков»? И разве художник масштаба Карла Орфа мог не задуматься над проблемой абсолютного бессилия человека, понимающего природу этого «гнева»?

История создания оперы-оратории «Бернауерин» интересна: в ноябре 1942 г. драма Фридриха Геббеля из средневековой жизни Баварии «Agnes Bernauer» была поставлена в Prinzregenten-Theater. Дочь Карла Орфа Годелла участвовала в спектакле и, как вспоминает композитор, пользовалась успехом публики и прессы. Немного переделав сюжет, Орф, в гораздо большей мере основываясь на народной балладе ${ }^{1}$, используя баварский диалект, который он хорошо знал, создает текст.

В 1944-1946 гг. Орф пишет музыку оперы «Бернауерин» и посвящает ее своему другу, арестованному мюнхенским гестапо

\begin{tabular}{|c|c|}
\hline \multicolumn{2}{|l|}{ Народная баллада } \\
\hline Три всадника скачут, три всадника мчатся & Едва три дня и три ночи прошли, \\
\hline Из Мюнхена. Всадники в дом стучатся. & До геричога скорбные вести дошли. \\
\hline «Tы здесь, тыл здесь, Бернауерин? & «Ее утопили в Дунае!» \\
\hline Бернауерин, скорее выйди к нам! & «Эй, рыбаки, собирайтесь сюда! \\
\hline Здесь ждет тебя гериог сам, & Закиньте скорее свои невода.До Черного моря ищите. \\
\hline Сам со своею свитой. Со свитой». & Ищ̧ите!» \\
\hline Бернауерин быстро, как только успела, & В рыбаиких сетях ее принесли. \\
\hline Белее снега рубаху надела. & У самого Черного моря нашли. \\
\hline Чтоб гериога встретить. Да, встретить. & У самого моря. \\
\hline И только вышла она за дверь, & И гериог стал ее труп обнимать \\
\hline Три всадника встали перед ней: & И слезы над ней без кониа проливать. \\
\hline «Теперь выбирай поскорее. Поскорее: & Так горько, так горько он плакал... Да, плакал. \\
\hline Согласна ты геричога потерять & и тотчас войско велел собрать, \\
\hline Или жизнь свою молодую отдать & Чтоб новую войну начать, \\
\hline Дунайским глубоким водам?» & Отиу отомстить за обиду. \\
\hline «Если гериога мне суждено потерять. & «Он был мне отиом и предал меня. \\
\hline То и жизнь свою я готова отдать & Как вора, его повешуя. \\
\hline Дунайским глубоким водам. Да, водам. & Мне это не будет позором». \\
\hline Герияог-мой, ая -его. & Едва три дня и три ночи прошли. \\
\hline Мыл любим друг друга оба & Гериогу новую весть принесли: \\
\hline И будем верны до гроба. До гроба». & Отеи его умер. Да, умер. \\
\hline Когда повели ее на мост. & «Кто хочет со мною отиа хоронить, \\
\hline Палач ей последний задал вопрос. & Краснее крови должен носить \\
\hline Задал вопрос последний. Последний. & Одежду. Краснее крови. \\
\hline «Что хочешь, моею женою стать & Кто будет любовь мою хоронить, \\
\hline Или гордое тело свое отдать & В черной одежде должен ходить, \\
\hline Дунайским глубоким водам?» & В черной одежде. Черной. \\
\hline «Женой палача мне стать не дано. & И будем служить мы тысячу дней \\
\hline Пусть тело мое идет на дно. & Вечную мессу в память о ней \\
\hline Глубокое дно Дуная. Дуная», & И ей молиться вечно. Да, вечно». [6] \\
\hline
\end{tabular}


27 февраля 1943 г. у него на глазах - Курту Хуберу, расстрелянному в июне 1943 г. Партитура оперы «Бернауерин» издана в 1946 году с надписью «In шеmoriam Kurt Huber» («Памяти Курта Хубера»). 15 июня 1947 года постановка оперы осуществляется в Штутгарте [5]. Первая часть оперы посвящена встрече сына баварского герцога Эрнста Альбрехта, властвующего в городе Баварии Штраубинге, с Агнес дочерью владельца Аугсбургских купален, зарождающейся любви, женитьбе Альбрехта на Агнес ${ }^{1}$.

По сути, вторая часть оперы интересует нас больше, чем история встречи и любви Альбрехта и Агнес. Вторая часть имеет непосредственное отношение к теме: именно во второй части разворачиваются трагические события «подталкивания» толпы к смерти Агнес. Вторая часть состоит из четырех картины, в которых появляются новые персонажи: монах, канцлер герцога, судья, сыщик (капитан), ведьмы (говорящий хор). Орф используемый в опере традиционный состав оркестра (без струнной группы): 3 флейты, 3 малые флейты (в клавираусцуге не указано, но, видимо, флейтыпикколо), 3 гобоя, 3 английских рожка, 3 кларнета (и бас-кларнет), 2 фагота, 4 валторны, 3 трубы, 3 тромбона, туба, челеста, арфа, 2 рояля, плюс к этому - огромный набор ударных инструментов: там-там, тарелки, 7 литавр, колокола, колокольчики, ксилофоны (включая басксилофон, треугольник, металлофон, трещотки и другие). Во второй части оперы используются следующие инструменты: 2 рояля, 2 малые литавры, тарелки, большой и малый тамтамы, большие и малые (6 штук) колокола (фа), малые барабаны (6 штук), трещотки, басксилофон, орган [цит. по: 4, s. 189].

Вторая часть, как и первая, начинается оркестровой «Интрадой», которая звучит празднично и торжественно.

\footnotetext{
${ }^{1}$ О. Леонтьева в своей книге о К. Орфе так пересказывает сюжет: «В баварской хронике сообщается, что прекрасная Агнес, дочь Каспара Бернауера из Аугсбурга, была выдана за Альбрехта (будущего герцога Альбрехта III Мюнхенского) в 1432 году, а 12 октября 1435 года по приказу его отца - правящего герцога Эрнста - была утоплена в Дунае как колдунья». Добавим, что Эрнст приказал построить в г. Штраубинг (где властвовал его сын, Альбрехт) часовню памяти убитой герцогини, которая по сей день сохранилась. В ХХ в. в городе ежегодно происходит фестиваль в честь Агнес. См.: [6].
} 


\section{Intrade}
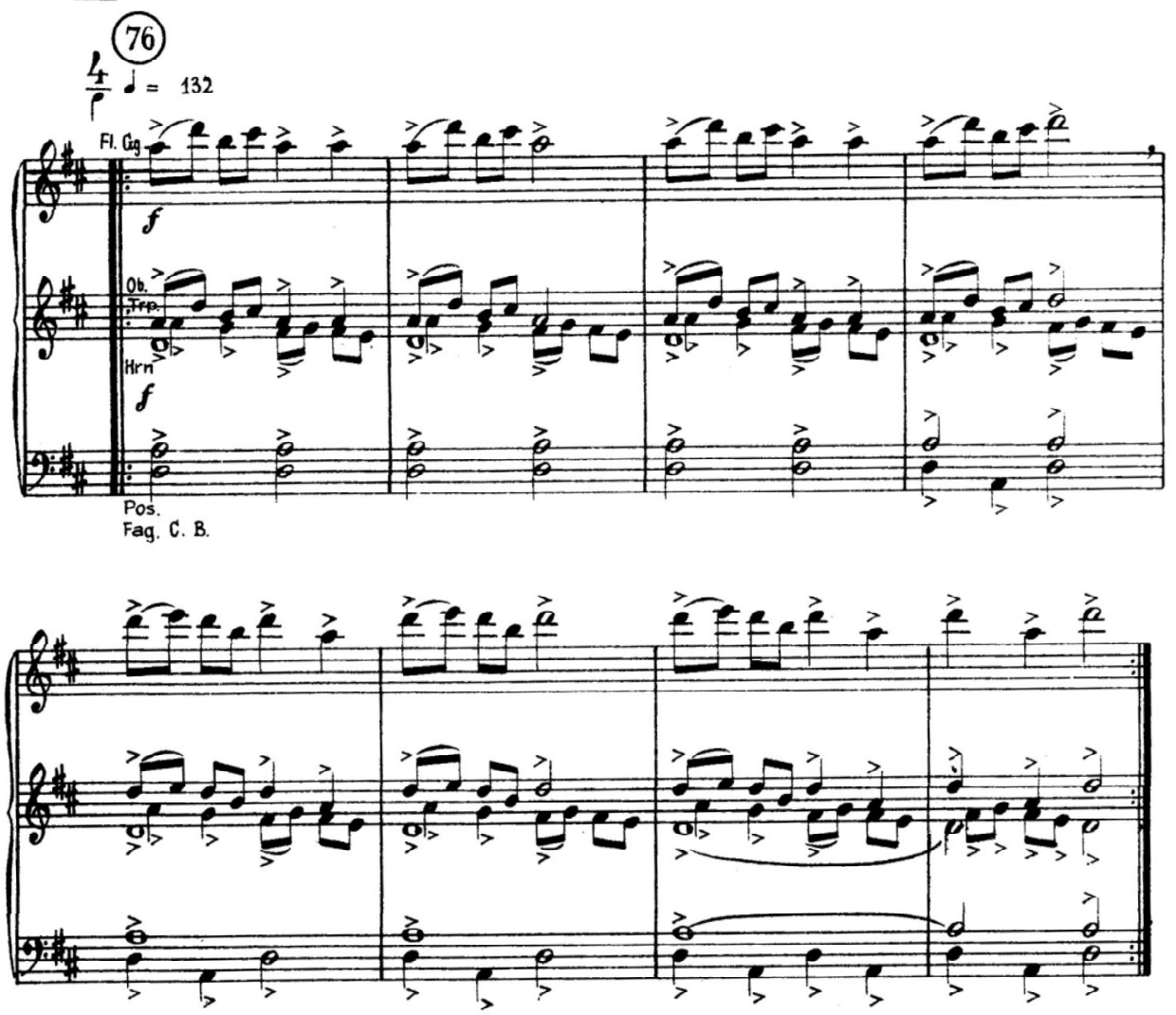

Вслед за этим фрагментом звучит настораживающий диалог (разговорная речь). Нужно оговориться: Карл Орф, так же как и Жорж Бизе (опера «Кармен»), пишет целостный спектакль с разговорными диалогами. При этом он требует от актеров быть, в первую очередь, актерами, а лишь затем - вокалистами.

Начинается первая картина второй части, в которой два мюнхенских бюргера обсуждают женитьбу Альбрехта на Агнес. Их мезальянс очень не нравится герцогу Эрнсту. Звучит фраза о том, что дети, внуки и правнуки какой-то банщицы (Агнес) будут сидеть на троне герцогства Мюнхена. Их диалог звучит после краткого оркестрового вступления к первой картине и не предвещает драматизма ни в музыкальном ${ }^{1}$, ни в сюжетном плане.

Третья картина подтверждает разговор двух бюргеров: канцлер герцога беспокоится о своем господине (герцог Мюнхена Эрнст), который, по его словам, «ночей не спит», заботясь о жителях Баварии. Сцена небольшая, однако, она дает представление о цели: мезальянс - недопустим (сын баварского герцога, будущий повелитель страны, не может жениться на дочери владельца купален)!

Вторую и пятую картину композитор посвятил Агнес Бернауерин. Уже здесь, особенно в монологе Агнес о колесе Фортуны, можно услышать

\footnotetext{
${ }^{1}$ Может быть, только секунда e-fis звучит немного напряженно.
} 
тревогу, подчеркнутую музыкальной интродукцией (повторяющиеся нисходящие секунды), которые звучат после монолога Агнес.
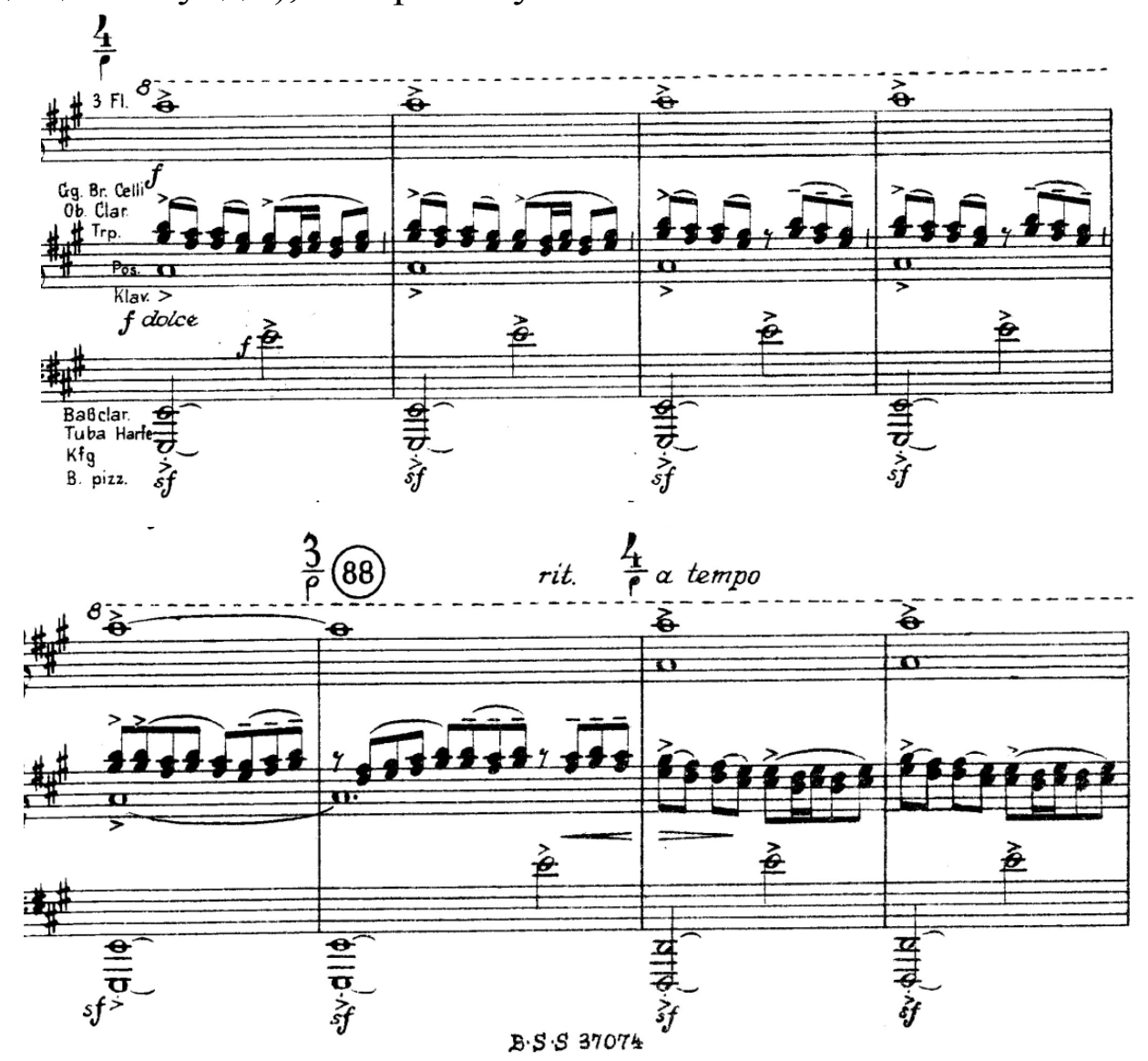

Главная сцена (четвертая картина): монах из Мюнхена побуждает толпу людей к обвинению Агнес (разговорная речь): «К нам скачут четыре всадника: Чума, Война, Голод, Смерть! Спасайтесь! Господи, помилуй! Ведьма околдовала Альбрехта! Долой Бернауерин! Ведьму - в волны Дуная!» - кричит толпе, посланный Эрнстом, Монах.

(Klappern und Ratschen)

Garrit gallus, garret gallus, wachts auf, wachts auf, wachts auf!

Kyrieleis, Kyrieleis, schreits: Kyrieleis!

Derbarm di Herr unser

Und unserner Sünd, Auf dass net der Teifl 
In uns

Handlanger findt.

И толпа, разгоряченная словами монаха, вторит ему. Вся картина идет без музыки. Монах и толпа скандируют текст. Лишь в самом конце сцены, сначала из-за сцены, потом все ближе раздается дробь барабана.

\section{Mönch : grell}

Nieder mit der Bernauerin !

\section{Volk : \\ Nieder mit der Bernauerin !}

\section{Mönch :}

Der Landsverderberin!

\section{Volk :}

Der Landsverderberin !

Думается, что клавираусцуг оперы «Бернауерин» неспроста снабжен только текстом (в котором даже нет указаний композитора на темп диалога Монаха и Толпы). Очевидно, что для композитора, который решает побуждения толпы к действию только драматическими средствами (без музыки) - драматическая кульминация всего сочинения.

В пятой картине, все происходящее в замке Альбрехта в городе Штраубинг, композитор реализует в двух сценах. Первая - лирическая, распевная песня Агнес, в которой возникает ощущение тревоги (Nun eh ich Lieb durch Leiden wollt lan eh will ich Lieb in han). Во второй звучит только речь Агнес, судьи, капитана и монаха (они объявляют ей волю герцога Баварии: Агнес необходимо утопить, как ведьму, околдовавшую Альбрехта). И Агнес гордо и с долей презрения говорит с судьей, капитаном, монахом, посланными еe утопить: «Я герцогиня Штраубинга! Ведите к Дунаю!».

В шестой картине второй части оперы-оратории «Бернауерин», которая начинается ударом тарелки, ведьмы (актеры в масках) комментируют происходящее. Актеры-ведьмы скандируют текст (произносят его, не распевают) в соответствии с ритмом и темпом, которые указал автор $(6 / 8$ и 9/8; $1 / 4 \quad$ - 160). Комментируя скороговоркой, они строго подчинены указанному в партитуре ритму и темпу. Сопровождают это скандирование, характерные для Орфа, ударные инструменты: бас-ксилофон, ксилофон, трещотки, б.барабан, литавры, там-там, тарелки. 

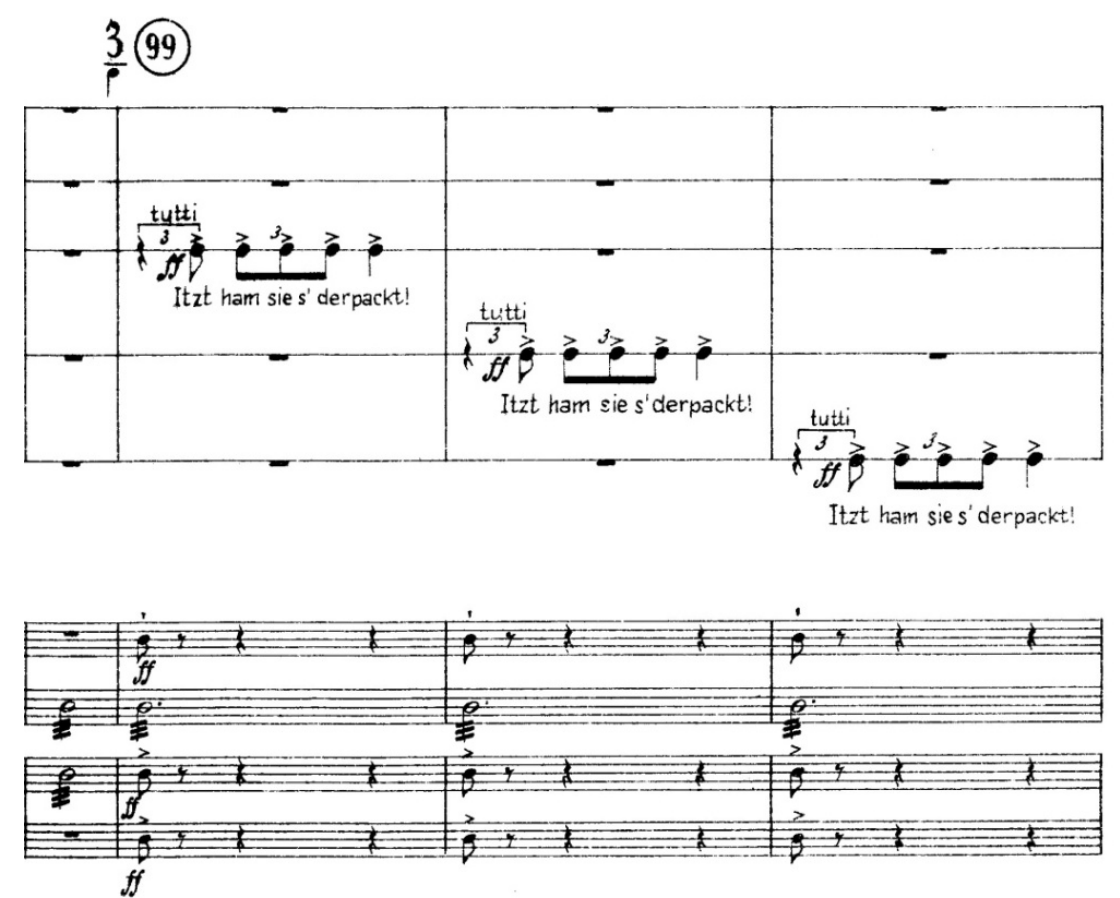

На фоне тремоло ксилофона ведьмы комментируют слушателю то, что происходит: «Везут в клетке, приводят на мост, поднимают над водой, бросают в воду (фальцет: даже рыбы закрывают глаза), никто не пытается помочь, вруны, убийцы, даже рыбы все уплыли, чтобы не слышать, как она кричала, умирая».

К. Орф считал, что исполняющие его произведения актеры должны быть не только профессиональными вокалистами, но, главное - актерами! Как это часто делает композитор, ксилофон, там-там, литавры, б.барабан и тарелки «обрывают» звучание скандирующего хора ведьм единым «ударом», предоставляя фальцету хористу возможность в полной тишине произнести «сакраментальную» фразу: «Die Fisch san Fortgschwommen, hats keiner vernommen wie s'gschrien hat im Tod» («Даже рыбы уплыли, чтобы не слышать, как она кричала, умирая»).

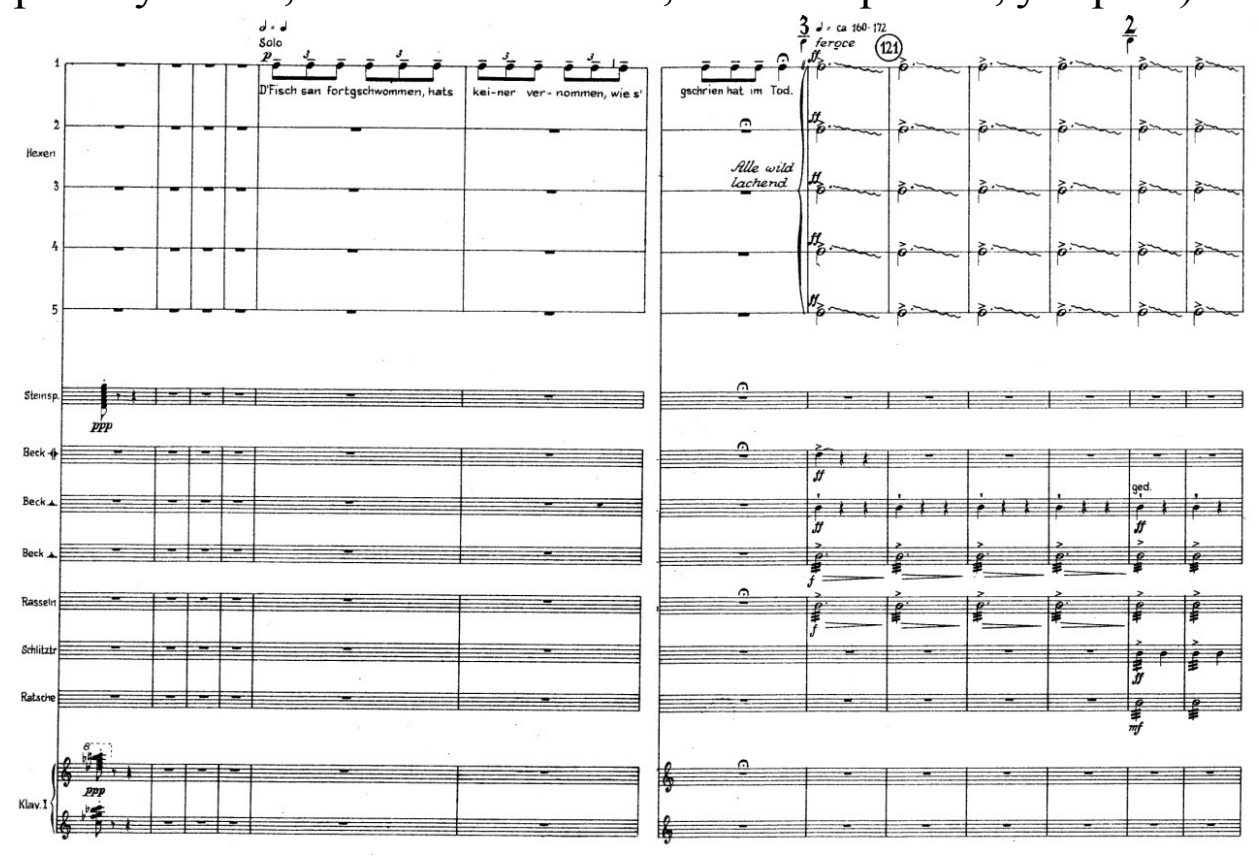


И хор ведьм начинает истово хохотать. В партитуре композитор обозначает смех ведьм 14 тактами: «Alle wild lachend!» («Bce дико смеются!»). Представляется, что эта картина - одна из главных: ведь, комментируя происходящее, ведьмы не стесняются в определении толпы («вруны», «убийцы»).

В седьмой картине народ оплакивает Агнес. В музыкальном материале это воплощается многократным повторением одной и той же ритмической фигуры (см.пример).

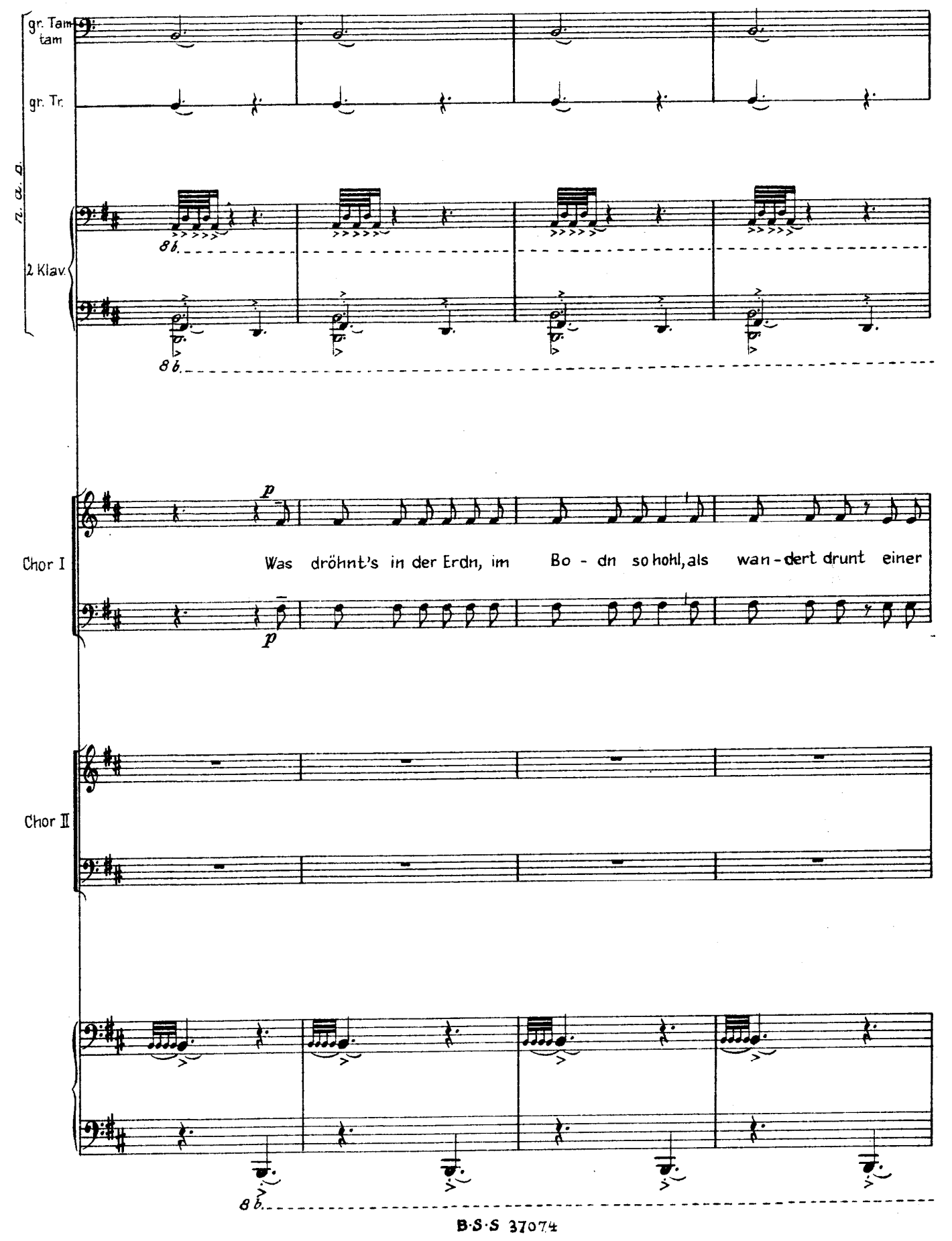


Наконец, у хора появляется фраза с нисходящей секундой (ремарка Glockn schlagn - Колокол ударяет). И лишь, когда раздается вопрос Альберта: «Wo ist die Bernauerin?» («Где Бернауерин?»), хор повторяет имя «D’Bernauerin, d'Bernauerin, d'Bernauerin! Die es ertrunken» («Бернауерин, Бернауерин, Бернауерин! Она утоплена»). Короткая фраза оканчивается несколько раз повторенной нисходящей секундой (ламентозная интонация).

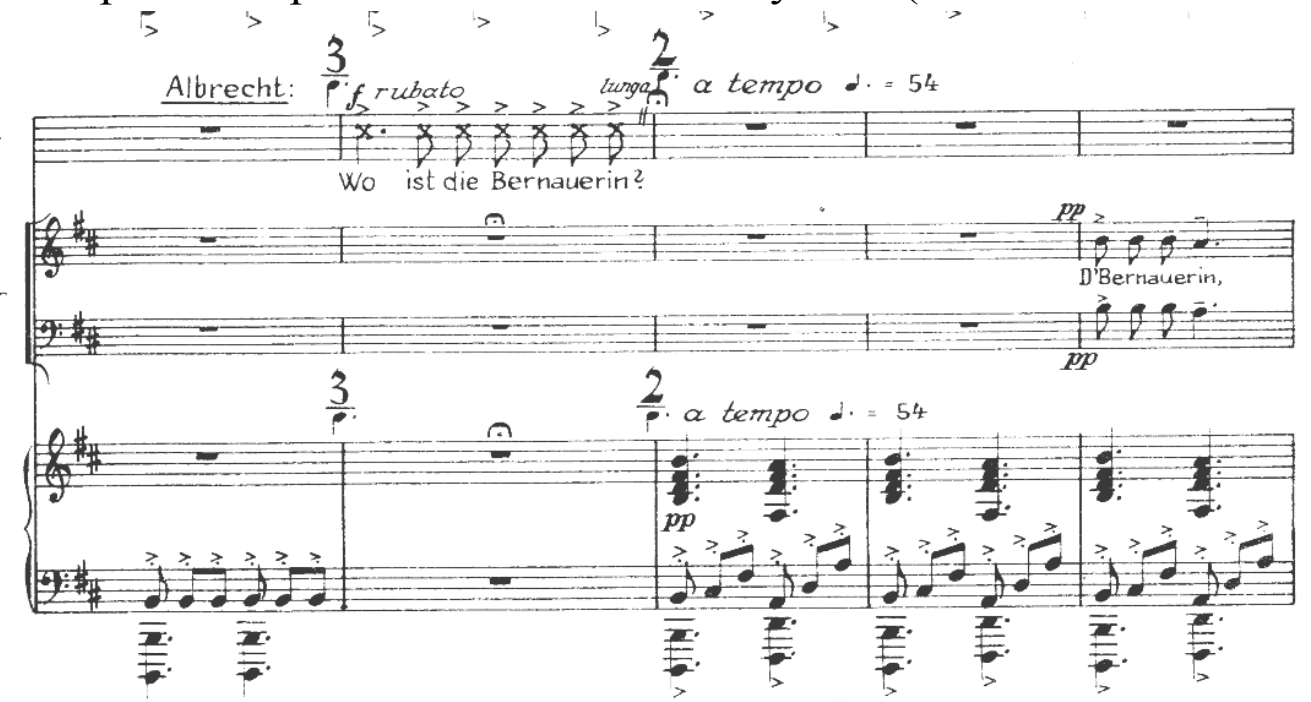

(137)

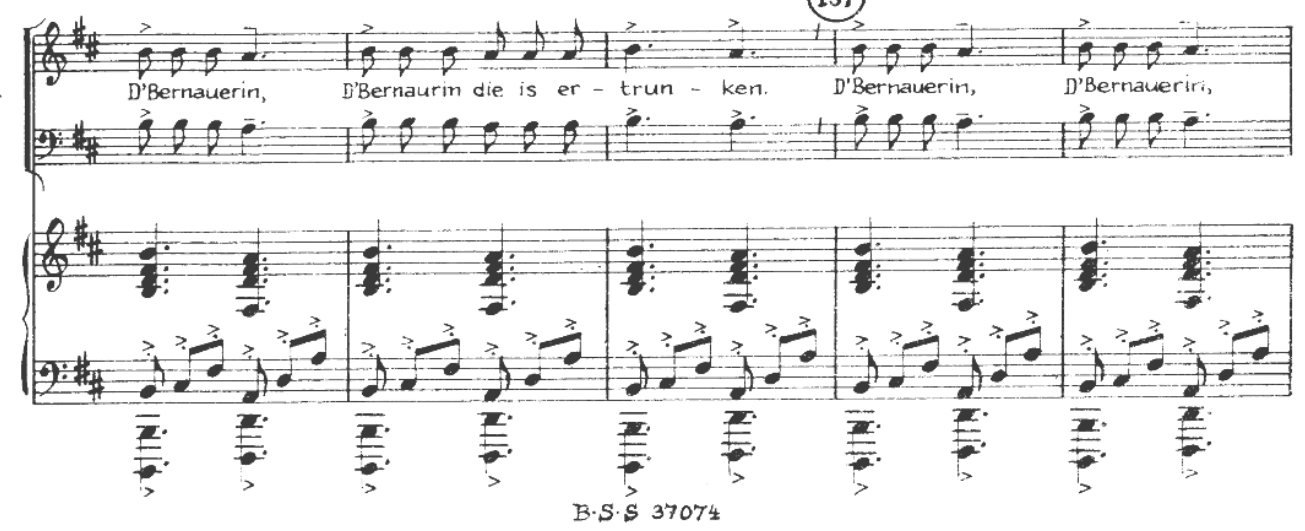

Часто встречается? Да часто. Но где? «Семь слов Спасителя на кресте» Й. Гайдна (начальные фразы оркестра достаточно коротки и оканчиваются нисходящей секундой), «Всенощное бдение» С. Рахманинова (каждая фраза «Придите и поклонимся» завершается нисходящей секундой), Месса си-минор И. С. Баха №15 «Crucifixus» (Был распят) (нисхождение «вниз» хора), ария Петра (№47) из «Пассионов по Матфею» И. С. Баха (каждая фраза солирующей скрипки оканчивается нисходящей секундой), Lacrimosa из «Реквиема» В. А. Моцарта (фразы хора, оканчивающиеся нисходящими секундами) и бесконечное множество подобных...

Таким образом, начиная с четвертой картины, зритель-слушатель наблюдает смерть Агнес. Исключение составляет только пятая картина, где 
Агнес произносит свой монолог и общается с посланцами. Интересно решает Орф задачу: смерть героини комментируется «ведьмами», толпа показана лишь позднее, «скорбящей», словно приходящей в себя, после морока (после вопроса Альбрехта: Wo ist die Bernauerin? - Где Бернауерин?).

О. Т. Леонтьева, которой принадлежит наиболее полное исследование творчества К. Орфа, считает, что в операх-сказках композитор «высмеивает» Третий Рейх, а в операх-трагедиях заставляет задуматься над природой тирании [6]. Между тем, внимательный взгляд обнаруживает на странице 8 книги «Карл Орф» О. Леонтьевой верную оценку скрытого смысла того, что положено в основу трагического восприятия мира композитором: роль «управляемой», «ведомой» толпы. Обратимся к тексту О.Т. Леонтьевой: «В „Бернауерин”, в „Хитрец̧ах” отчасти в „Луне” Орф настойчиво указывает зрителю еще одну, с его точки зрения, чрезвычайно важную проблему общечеловеческого звучания, которую он делает темой своего критически анализирующего творчества. Это давняя тема: человеческая масса, огромная толпа, обманутая, загипнотизированная лозунгами люживой пропаганды. Есть у Орфа „,внеисторическая”, сказочная людская толпа, замороченная весельми фокусниками и хитрыми стяжателями. Это „Хитрецьь” и „Луна”. Здесь глупых горожан всего лишь обкрадывают, оставляют с носом или заставляют платить талеры „за лунный свет”. Но страшная толпа в „Бернауерин” - конкретно-историческая толпа. Ей грозят „божьей карой”, ее призывают „ловить ведьму”, искать ее в своих рядах, среди стоящих вблизи людей, и толпа воспламеняется ненавистью и жаждой расправыл. И зритель не может в это время не вспомнить о восторгах толпь, слушавшей речи «фюрера», ликовавщей на его военных парадах и гражданских церемониях фамичттской империи. Орф боится этой одураченной людской массы, и страх его передается зрителю как в исторически достоверной „Бернауерин”, так и в сказочнонеконкретных, карикатурных „Хитрецах” и „Луне”. Тема „,толпьи”, как уже сказано, представлена Орфом в двух планах: трагедийно и карикатурно» [цит. по: 6, с. 8].

Теперь мы знаем, что охранник Мюнхенского университета, который вызвал полицию, когда Софи Шоль разбрасывала листовки в вестибюле университета, был одним из этой толпы.

Хотелось бы перечислить всех студентов Мюнхенского университета - активных участников организации. Это:

- Ганс Шолль (р. 1918), один из организаторов «Белой Розы», студент медицинского факультета. 
- Софи Шолль (р. 1921), студентка философского факультета (казнены 22 февраля 1943 года после трёх дней допросов и пыток).

- Александр Шморель (р. 1917), эмигрант из России, один из организаторов «Белой Розы», студент медицинского факультета. В 2007 году причислен к лику местночтимых святых Германской епархией РПЦЗ. После войны улица Мюнхена, где жил А. Шморель, получила его имя (казнён 13 июля 1943 года в мюнхенской тюрьме Штадельхайм).

- К Курт Хубер (р. 1893), профессор философии Мюнхенского университета (казнён 13 июля 1943 года в мюнхенской тюрьме Штадельхайм).

- Вилли Граф (р. 1918), студент медицинского факультета (казнён 12 октября 1943 года).

- Ганс Лейпельт (р. 1921), студент химического факультета (казнён 29 января 1945 года).

- Ганс Хирцель (1924-2006), был приговорён к пяти годам лишения свободы, освобождён в 1945, кандидат в президенты ФРГ.

- Сузанна Хирцель (1921-2012), сестра Ганса Хирцеля, была приговорена к шести месяцам лишения свободы за недостаточностью доказательств, после войны преподавала виолончель, была, как и её брат, политически активна в партии «Республиканцы», выступала против правых и левых экстремистов и позднее против исламизации Европы.

Курт Хубер, казненный гитлеровцами в июне 1943 г., не имел устойчивых антирежимных взглядов. Он, как и Януш Корчак, не мог оставить своих любимых студентов на съедение «волкам». Он, сочинивший по их просьбе текст о свободе личности, не имел в виду сопротивляться правящему режиму, справедливо считая ограничение гражданских прав прерогативой Господа, а не чиновников III Рейха. Карл Орф, посвятивший оперу-ораторию «Бернауерин» своему другу Курту Хуберу, поставил ему памятник в веках! Ибо он, Карл Орф, понимал, что ведомая опытными «предводителями» толпа - самое страшное оружие!

1. Deutsche Übersetzung: Komponisten im Nationalsozialismus. Acht Porträts. ParthasVerlag, Berlin 2004.

2. Harper A. Carl Orff - Alpha or Omega//The musical times, January 1956.

3. Michael H. Kater Composers of the Nazi era: eight portraits. Oxford University Press, New York, Oxford, 2000.

4. Orff C. Die Bernauerin eine bairische Stück. Klavier-Ausyug. Edition 3997. B. Schott's Söhne, Mainz, 1947. S. 189.

5. Orff G. «Mein Vater Karl Orff und ich» by Henschel Verlag in der Seemann Henschel GmbH \& Co. KG, 2008, 159 p.

6. Леонтьева О. Карл Орф. М., 1964. С. 160. 
7. Maccoвble беспорядки.

$U R L:$ https://ru.wikipedia.org/wiki/\%D0\%9C\%D0\%B0\%D1\%81\%D1\%81\%D0\%BE\%D0\%B2\%D1 $\% 8 B \% D 0 \% B 5 \% D 0 \% B 1 \% D 0 \% B 5 \% D 1 \% 81 \% D 0 \% B F \% D 0 \% B E \% D 1 \% 80 \% D 1 \% 8 F \% D 0 \%$ B4\%D0\%BA\%D0\%B8 (дата обращения: 22.02.2018).

8. Поспелов П. Грановская Карл Орф и его фортуна//Газета «Коммерсантъ» №131 от 15.07.1995. URL: https://www. kommersant.ru/doc/113443 (дата обращения: 22.02.2018).

\section{References}

1. Deutsche Übersetzung: Komponisten im Nationalsozialismus. Acht Porträts. ParthasVerlag, Berlin 2004 [in Germany].

2. Harper, A. (1956). Carl Orff - Alpha or Omega. «The musical times», January [in English].

3. Michael, H. (2000). Kater Composers of the Nazi era: eight portraits. Oxford University Press, New York, Oxford [in English].

4. Orff, C. (1947). Die Bernauerin eine bairische Stück. Klavier. Ausyug. Edition 3997. B. Schott's Söhne, Mainz, S. 189 [in Germany].

5. Orff, G. (2008). "Mein Vater Karl Orff und ich» by Henschel Verlag in der Seemann Henschel GmbH \& Co. KG, 159 p. [in Germany]

6. Leonteva, O. (1964). Karl Orff. Moscow, p. 160 [in Russian].

7. Mass riots [Massovyie besporyadki]. Available at: https://ru.wikipedia.org/wiki/\%D0\%9C\%D0\%B0\%D1\%81\%D1\%81\%D0\%BE\%D0\%B2\%D1 $\% 8 B \% D 0 \% B 5 \% D 0 \% B 1 \% D 0 \% B 5 \% D 1 \% 81 \% D 0 \% B F \% D 0 \% B E \% D 1 \% 80 \% D 1 \% 8 F \% D 0 \%$ B4\%D0\%BA\%D0\%B8 (дата обращения: 22.02.2018) [Accessed 22.02.2018] [in Russian].

8. Pospelov P., Granovskaya A. Carl Orff and his fortune // The newspaper «Kommersant» №131 from 15.07.1995 [Karl Orffi ego fortuna // Gazeta «Kommersant'» №131 ot 15.07.1995]. URL: https://www.kommersant.ru/doc/113443 [Accessed 22.02.2018] [in Russian]. 